\title{
New developments in vibration assisted machining of aerospace materials
}

\author{
Nowe osiągnięcia w obróbce materiałów lotniczych wspomaganej drganiami
}

KRZYSZTOF JEMIELNIAK*

DOI: https://doi.org/10.17814/mechanik.2021.8-9.13
Presented is an update of the recent literature on advances in difficult to machine materials such as nickel and titanium-based alloys, and composites used in aeroengine and aerostructure applications. The review covers ultrasonic vibration-assisted machining and the combination of this technique with minimum quantity lubrication and high-pressure cooling. Also discussed are low-frequency vibration-assisted aerospace alloy drilling and low- and high-frequency vibration-assisted drilling of stacks.

KEYWORDS: aerospace materials, machining, vibrations, UVAM, UVAM\&MQL, UVAM\&HPC, LF-VAD

Przedstawiono najnowsze osiągnięcia we wspomaganej drganiami obróbce materiałów trudnoobialnych, takich jak stopy niklu, stopy tytanu oraz kompozyty stosowane w silnikach i konstrukcjach lotniczych. Przegląd obejmuje obróbkę wspomaganą drganiami ultradźwiękowymi oraz połączenie tej techniki ze smarowaniem minimalnym i chłodzeniem pod wysokim ciśnieniem. Omówiono także wiercenie stopów lotniczych wspomagane drganiami o niskiej częstotliwości oraz wiercenie stosów wspomagane drganiami o niskiej i wysokiej częstotliwości.

SŁOWA KLUCZOWE: materiały lotnicze, obróbka skrawaniem, drgania, obróbka wspomagana drganiami ultradźwiękowymi, minimalne smarowanie, wiercenie wspomagane drganiami o niskiej częstotliwości, chłodzenie pod wysokim ciśnieniem

\section{Wprowadzenie}

Doskonałe właściwości mechaniczne i chemiczne nadstopów są jednocześnie powodem ich słabej obrabialności i niezadowalającej jakości warstwy wierzchniej. Materiały kompozytowe, takie jak polimer wzmocniony włóknem węglowym (CFRP), są wprowadzane do projektowania i produkcji samolotów w celu poprawy ich cech (lekkości i wytrzymałości), jakości, obniżenia kosztów cyklu życia i konserwacji oraz kosztów produkcji i skrócenia czasu realizacji. Uszkodzenia powstające podczas obróbki mechanicznej materiałów kompozytowych zmniejszają ich wytrzymałość i trwałość zmęczeniową. Najpoważniejszym uszkodzeniem wynikającym z wiercenia materiałów kompozytowych jest rozwarstwienie na powierzchniach otworów. Aby rozwiązać te problemy, stosuje się wysoko wydajne techniki chłodzenia oraz obróbkę wspomaganą drganiami. Te pierwsze zostały omówione $\mathrm{w}$ poprzednim artykule [1], tu zostaną omówione najnowsze osiągnię- cia (z lat 2018-2020) w sposobach wspomagania obróbki materiałów lotniczych drganiami:

- obróbka wspomagana drganiami ultradźwiękowymi (ultrasonic vibration assisted machining - UVAM),

- połączenie wspomagania drganiami ultradźwiękowymi ze smarowaniem minimalnym (ultrasonic vibration assisted machining \& minimum quantity lubrication - UVAM\&MQL),

- połączenie wspomagania drganiami ultradźwiękowymi z chłodzeniem wysokociśnieniowym (ultrasonic vibration assisted machining \& high-pressure cooling UVAM\&HPC),

- wiercenie wspomagane drganiami o niskiej częstotliwości (low-frequency vibration assisted drilling LF-VAD).

\section{Obróbka wspomagana drganiami ultradźwiękowymi}

Obróbka wspomagana drganiami ultradźwiękowymi (UVAM) to proces, w którym w celu poprawy wydajności skrawania do narzędzia lub przedmiotu obrabianego przykładane są wibracje o wysokiej częstotliwości i małej amplitudzie. Oscylacje krawędzi skrawającej w zakresie kilku mikrometrów powodują zmianę prędkości skrawania i/lub posuwu o wysokiej częstotliwości. Dzięki temu można osiągnać: zmniejszenie sił skrawania, zwiększenie trwałości narzędzia i poprawę jakości obrabianego przedmiotu.

UVAM zastosowano $\mathrm{w}$ kilku procesach obróbki, $\mathrm{w}$ tym $\mathrm{w}$ wierceniu, toczeniu, szlifowaniu, frezowaniu, a ostatnio w obróbce materiałów trudnoobrabialnych. Bieżący tor narzędzia wspomaganego drganiami nakłada się ze śladem pozostawionym na powierzchni skrawania w poprzednim przejściu, co może powodować przerwanie kontaktu z obrabianym przedmiotem i powstawanie nieciągłych wiórów. Historię i aktualny stan urządzeń do UVAM, w tym teorię i zasady ich projektowania przedstawiono $\mathrm{w}$ [2] i [3]. W ostatnich latach kilka artykułów zostało poświęconych zastosowaniu UVAM przy obróbce stosowanego często w przemyśle lotniczym stopu Ti6Al4V.

Kompleksowe badania eksperymentalne wpływu drgań wzdłużnych (LVAM) i wzdłużno-skrętnych (LTVAM) na siłę skrawania, trwałość narzędzia i jakość powierzchni podczas frezowania Ti6Al4V

* Prof. dr hab. inż. Krzysztof Jemielniak, krzysztof.jemielniak@pw.edu.pl, https://orcid.org/0000-0002-7156-7878 - Wydział Inżynierii Produkcji, Politechnika Warszawska, Warszawa, Polska 


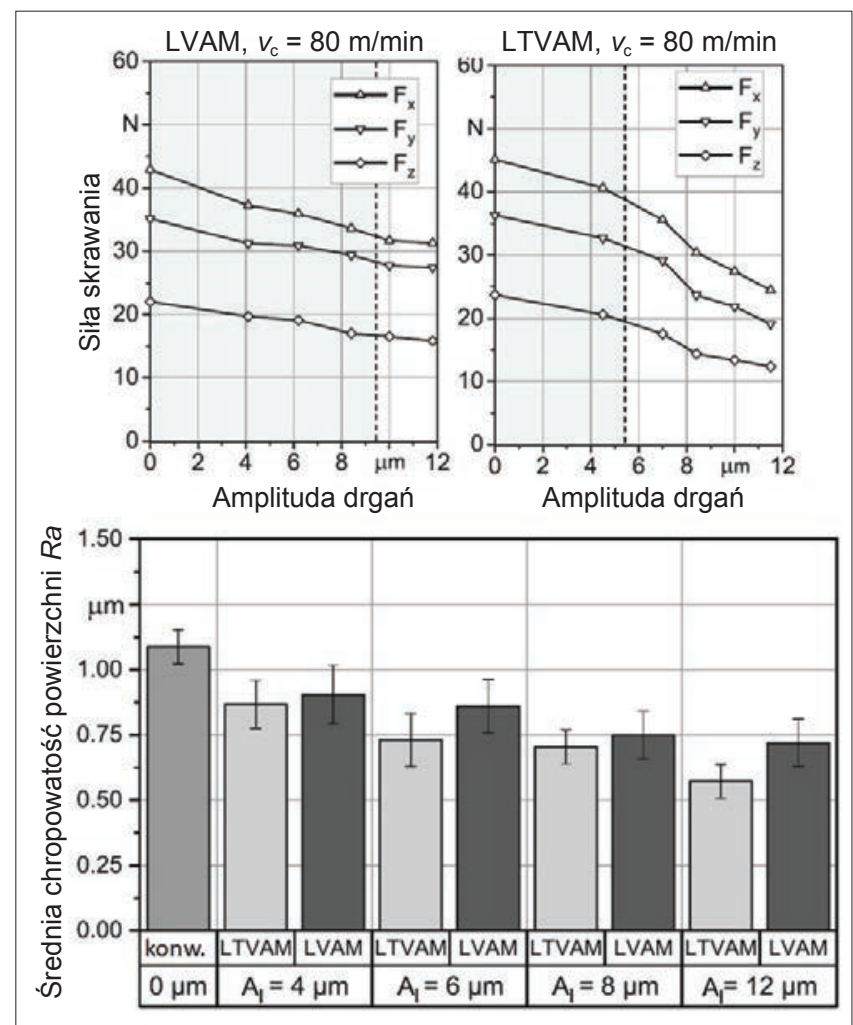

Fig. 1. Cutting forces and surface roughness for peripheral milling at different vibration amplitudes for LVAM and LTVAM [4]

Rys. 1. Siły skrawania i chropowatość powierzchni dla frezowania obwodowego przy różnych amplitudach drgań dla LVAM i LTVAM [4]

przedstawiono w [4]. Zastosowanie LTVAM w większym stopniu poprawiło ogólną wydajność procesu niż same drgania wzdłużne. Siły skrawania zmniejszają się średnio o 44,3\% w LVAM i o 57\% w LTVAM, ponieważ składowa drgań skrętnych prowadzi do skrócenia czasu kontaktu między narzędziem a przedmiotem obrabianym (rys. 1). Chropowatość dolnej powierzchni próbek frezowanych pełną średnicą frezu zmniejsza się od $R a=0,9 \mu \mathrm{m}$ do 0,78 $\mu \mathrm{m}$ (LVAM) i 0,75 $\mu \mathrm{m}$ (LTVAM). LVAM i LTVAM podczas frezowania rowków mogą znacznie zwiększyć szczątkowe naprężenia ściskające i twardość powierzchni. Wydłużenie okresu trwałości ostrza, niższe siły skrawania, lepszą chropowatość powierzchni i niższą temperaturę skrawania podczas frezowania UVAM stopu Ti6Al4V w porównaniu z frezowaniem konwencjonalnym zaobserwowano także w [5].

Bliższe przyjrzenie się mechanizmowi generowania mikrotekstury obrobionej powierzchni i wpływowi na jej właściwości tribologiczne po obróbce UVAM stopu Ti6Al4V wykazało, że przestrzeń wytwarzana między frezem a obrabianym materiałem może znacznie zmniejszyć kumulację ciepła w strefie skrawania i wzmocnić smarowanie aerodynamiczne przy zmniejszonym tarciu [6]. Ponadto ciągłe zmiany prędkości względnej, przyspieszenia względnego i odwróconej siły tarcia między narzędziem a przedmiotem są również pomocne w usuwaniu wiórów. Jednolita mikrotekstura może znacząco poprawić morfologię i jakość powierzchni. Duża liczba śladów narzędzia składających się z wklęsłości, wybrzuszeń i nierówności występujących na powierzchniach obrabianych konwencjonalnie zasadniczo różni się od jednorodnej tekstury powierzchni wytworzonej techniką UVAM (rys. 2).

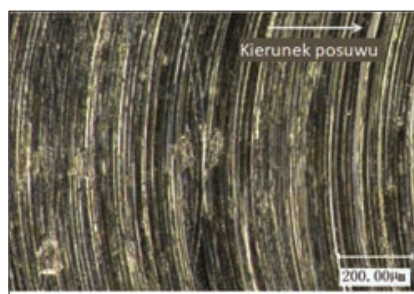

Frezowanie konwencjonalne

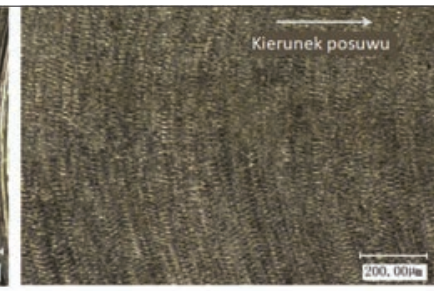

UVAM
Fig. 2. Comparison surface morphology between conventional milling and UVAM of Ti6AI4V [6]

Rys. 2. Porównanie morfologii powierzchni Ti6Al4V frezowanej konwencjonalnie i z UVAM [6]

Segmentacja wiórów podczas obróbki Ti6Al4V powoduje oscylacje naprężeń i temperatury na krawędzi narzędzia, co prowadzi do szybkiego zużycia ostrza i uszkodzenia obrabianej powierzchni. Badania mikrostruktury wiórów wykazały, że pasma ścinania zanikają po zastosowaniu UVAM wzdłuż kierunku stycznego przy określonych prędkościach skrawania [7]. Częstotliwość zmian temperatury i naprężeń zależy od częstotliwości drgań. W rezultacie długość podziałki segmentacji wióra jest określana raczej przez tę częstotliwość i prędkość skrawania niż przez grubość skrawanej warstwy.

Zastosowanie UVAM do toczenia Inconelu 718 i 625 również prowadziło do znacznego zmniejszenia siły skrawania i poprawy chropowatości powierzchni oraz generowało większe naprężenia ściskające w porównaniu $\mathrm{z}$ tymi w konwencjonalnym toczeniu [8].

Innym zastosowaniem UVAM, które pojawiło się w ostatnich latach, jest obróbka kompozytów i materiałów warstwowych. Kompozyty z osnową z węglika krzemu wzmocnionego włóknem węglowym (C/SiC) są typowymi materiałami trudnymi do skrawania ze względu na wysoką twardość i kruchość. Głównym mechanizmem zużycia frezu z powłoką diamentową jest zużycie ścierne, a główną formą zużycia jest łuszczenie powłoki. W porównaniu z tradycyjnym frezowaniem dzięki zastosowaniu UVAM można zmniejszyć zużycie narzędzia, które najpierw maleje, a następnie rośnie wraz ze wzrostem amplitudy drgań - rys. 3 [9].

Kompozyty na osnowie $\mathrm{z}$ aluminium (SiCp/Al) wzmacniane cząstkami węglika krzemu odgrywają ważną rolę w przemyśle lotniczym, kosmicznym, elektronicznym, samochodowym i innych branżach ze względu na swoje doskonałe właściwości mechaniczne. Jednak obecność cząstek SiC prowadzi do niskiej wydajności obróbki, fatalnej jakości powierzchni i znacznego zużycia narzędzi. Wyniki eksperymentalnej analizy UVAM i konwencjonalnego toczenia $25 \%$ SiCp/Al świadczą o znacznym zmniejszeniu sił skrawania oraz chropowatości obrabianej powierzchni [10]. Zastosowania UVAM do frezowania 20\% SiCp/Al wskazały, że wzrost amplitudy ma niewielki wpływ na siłę skrawania i chropowatość powierzchni. Jednakże, gdy amplituda wzrasta do $3 \mu \mathrm{m}$, wzrasta nagle siła skrawania i chropowatość powierzchni. Dlatego też amplituda UVAM $3 \mu \mathrm{m}$ może być stosowana jako punkt odniesienia w kolejnych badaniach obróbki kompozytów 20\% $\mathrm{SiCp} / \mathrm{Al}[11]$. 

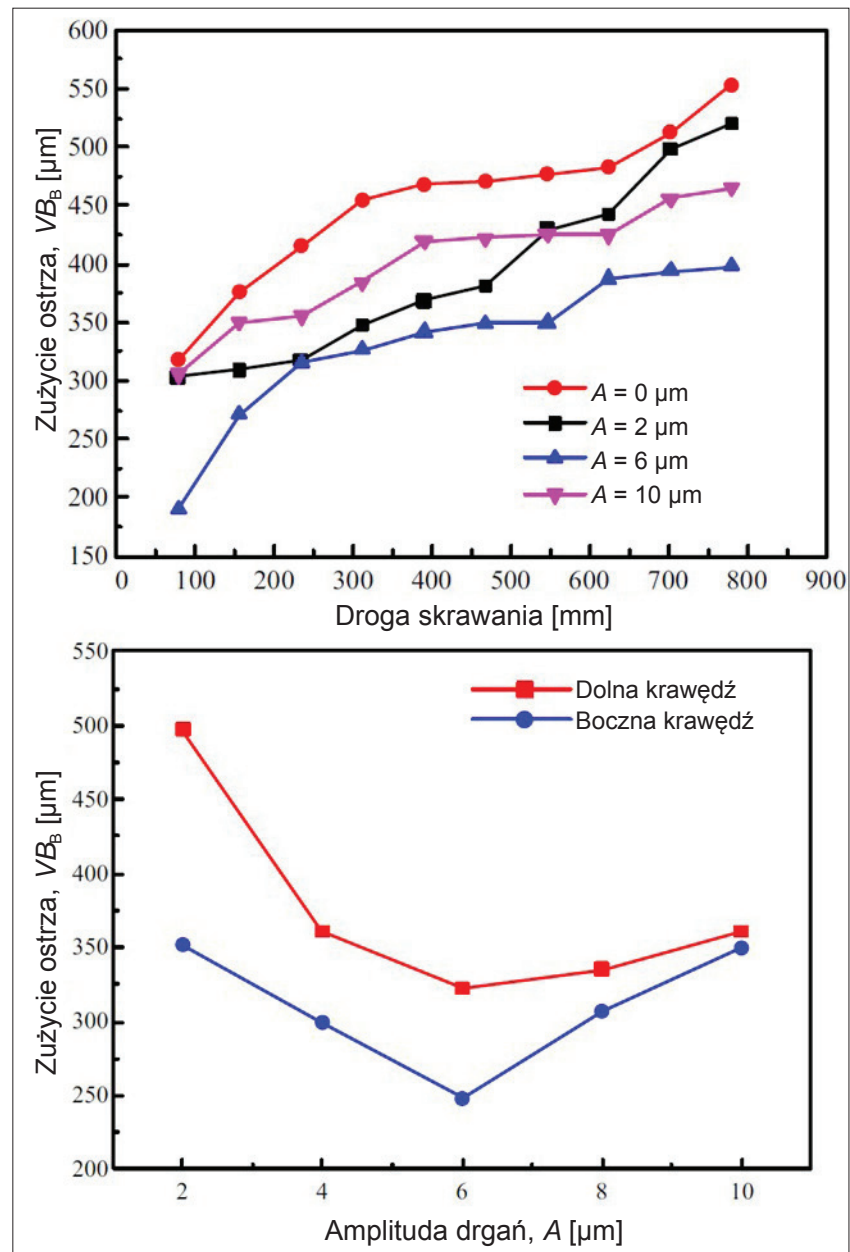

Fig. 3. Tool wear curve and effect of ultrasonic amplitude on tool wear [9]

Rys. 3. Krzywa zużycia narzędzia i wpływ amplitudy ultradźwięków na zużycie narzędzia [9]

Zastosowanie wiercenia wspomaganego drganiami o wysokiej częstotliwości (tu: $1500 \div 2150 \mathrm{~Hz}, 32 \div 65$ cykli/obr) do stosu CFRP/Ti6Al4V wykazało redukcję siły posuwowej o $26 \%$, temperatury w strefie obróbki o 37\% i o 86\% niższą wysokość zadziorów na wyjściu w porównaniu z wierceniem konwencjonalnym. Umożliwiło również uniknięcie rozwarstwiania CFRP z jednoczesnym występowaniem ściskających naprężeń szczątkowych na powierzchni Ti6Al4V, co może zwiększyć trwałość zmęczeniową obrabianej czesści [12].

Badania wydajności wiercenia wspomaganego ultradźwiękami (UAD) w obróbce materiału laminowanego Ti6Al4V/Al2024T351 wykazały, że dzięki UAD powstają kruche wióry, mniejsze są: rozwarstwienie warstwy, siła nacisku i naprężenie efektywne, a większa jest temperatura maksymalna [13]. Ultradźwięki wytwarzają wysoką energię lokalną w obrabianym przedmiocie, co pozwala na osiągnięcie efektu przy mniejszej sile wiercenia. Maksymalna temperatura warstwy tytanu przy zastosowaniu UAD i warstwy aluminium wzrosła odpowiednio o 6,2\% i 10,3\%. Ciepło wytwarzane przez drgania ultradźwiękowe nie może być szybko rozproszone, co powoduje wzrost temperatury narzędzia. Naprężenia zastępcze warstwy tytanowej i warstwy aluminium zmniejszyły się odpowiednio o $23,1 \%$ i $31,3 \%$, zmniejszając zużycie narzędzia - rys. 4.

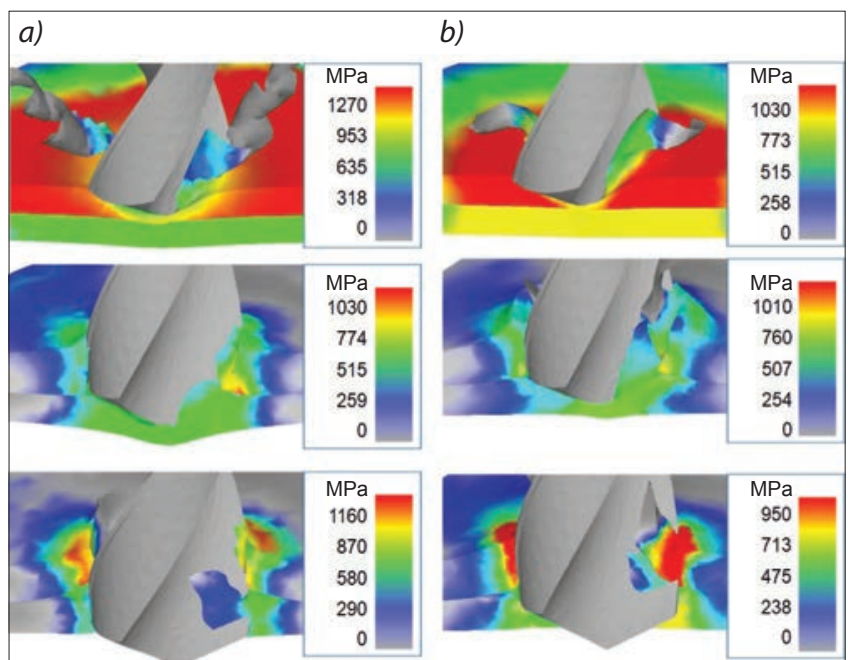

Fig. 4 . The equivalent stress diagram of: $a$ ) conventional drilling and b) ultrasonic-assisted drilling at different positions (cut the workpiece through the center of the circle) [13]

Rys. 4. Wykres naprężeń zastępczych dla: a) wiercenia konwencjonalnego i b) wiercenia wspomaganego ultradźwiękami w różnych położeniach (przekrój przedmiotu przez środek okręgu) [13]

\section{Połączenie wspomagania drganiami ultradźwiękowymi ze smarowaniem minimalnym}

Niezależnie od korzyści płynących ze stosowania smarowania minimalnego MQL, mgła olejowa wywołuje negatywne skutki dla przestrzeni roboczej, stwarzając potencjalne zagrożenie dla zdrowia operatorów maszyn. $\mathrm{Z}$ tego powodu podejmuje się próby połączenia zalet drgań ultradźwiękowych i smarowania MQL (UVAM\&MQL) bez tworzenia mgły olejowej. Ponadto - ze względu na zalety obu tych technik - oczekuje się, że ich jednoczesne stosowanie może jeszcze bardziej poprawić wydajność obróbki stopów tytanu.

Do toczenia Ti6Al4V zastosowano ciągłe smarowanie krawędzi skrawającej i drgania ultradźwiękowe (U-CMQL) bez wytwarzania mgły olejowej [14]. Bezzaworowa mikropompa dostarcza niewielkie ilości płynu (rys. 5). Technika U-CMQL nie tylko zapewnia schludność obszaru roboczego, ale także w pewnym stopniu poprawia skrawalność. W porównaniu z obróbką na sucho i obróbką wspomaganą ultradźwiękami w U-CMQL, dzięki połączeniu zalet smarowania i drgań, występują: niższa siła skrawania i mniejsze zużycie ostrza. Ponadto uzyskuje się skrócenie kontaktu narzędzie-wiór, korzystną morfologię wióra oraz lepszą jakość warstwy wierzchniej (rys. 5).

Porównanie frezowania Ti6Al4V konwencjonalnego, wspomaganego drganiami ultradźwiękowymi w kierunku posuwu (UVAM) oraz UVAM\&MQL wykazało, że zużycie narzędzia przy UVAM było zdominowane przez obciążenie dynamiczne. Siła skrawania o częstotliwości ultradźwiękowej, tarcie, uderzenia i punkty przegięcia skrawania trajektorii narzędzia oddziaływały jednocześnie na krawędzie skrawające. Morfologia zużycia narzędzi przy UVAM charakteryzowała się głównie pękaniem naroża, pękaniem uderzeniowym, śladami tarcia i pękaniem zmęczeniowym. Właściwości obrobionych powierzchni wskazują, że w porównaniu z powierzchniami uzyskanymi konwencjonalnie technika UVAM\&MQL może znacząco poprawić jakość 

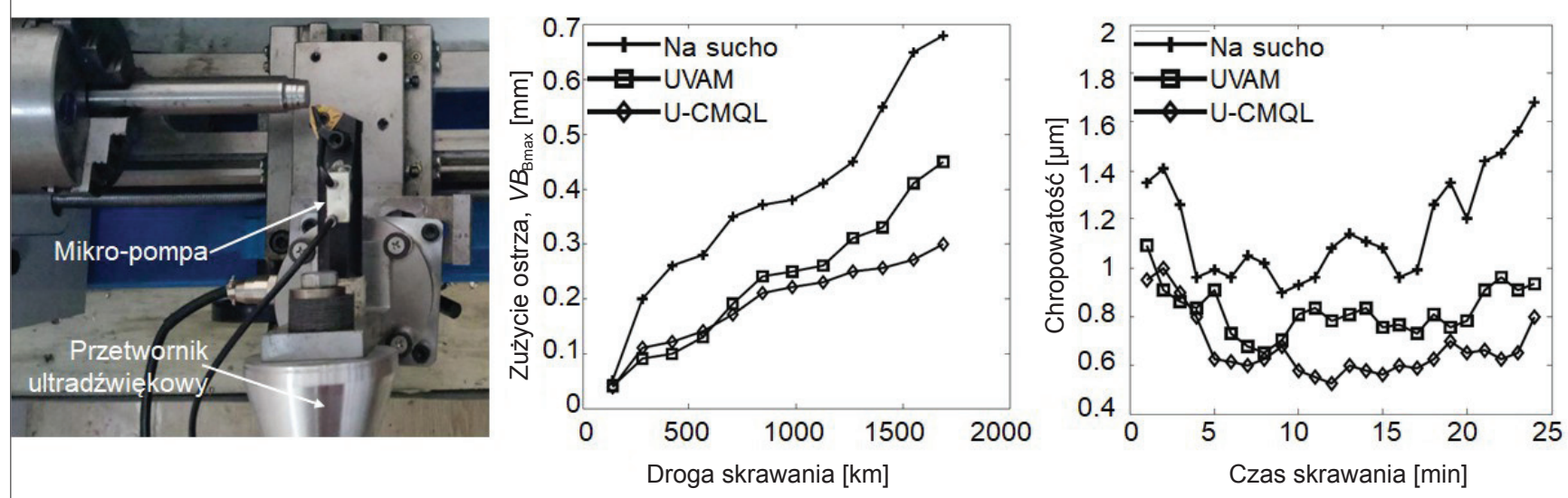

Fig. 5. Experimental setup, flank wear with cutting length and surface roughness under different cooling conditions [14]

Rys. 5. Stanowisko badawcze, zużycie powierzchni przyłożenia i chropowatość obrobionej powierzchni w różnych warunkach chłodzenia [14]

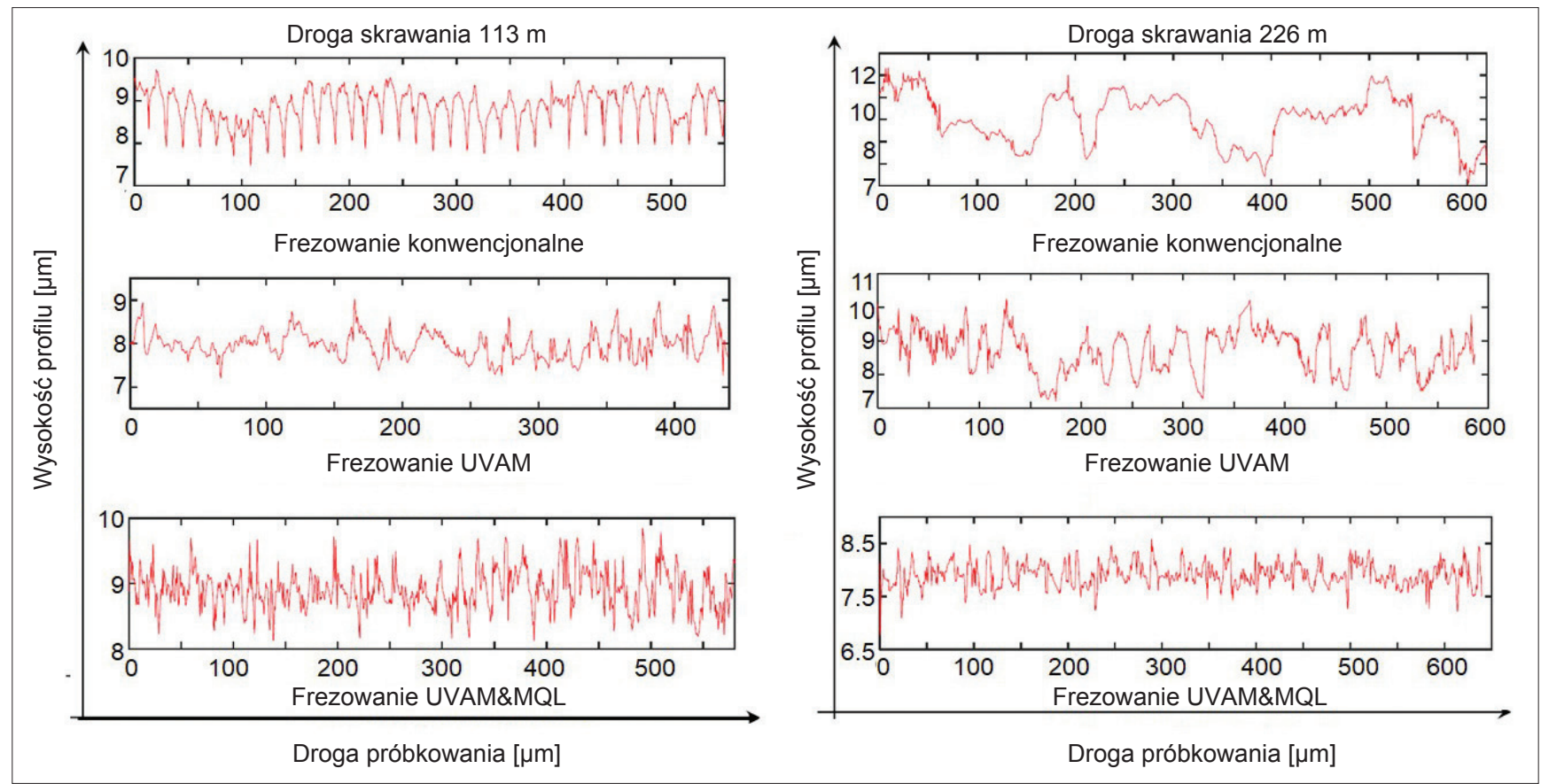

Fig. 6. Surface profile under conventional, UVAM and UVAM\&MQL milling of Ti6AI4V after the cutting distance of the cutter $113 \mathrm{~m}$ and $226 \mathrm{~m}$ [15] Rys. 6. Profil powierzchni przy frezowaniu Ti6Al4V konwencjonalnym, UVAM i UVAM\&MQL po długości przejścia $113 \mathrm{~m}$ i $226 \mathrm{~m}$ [15]
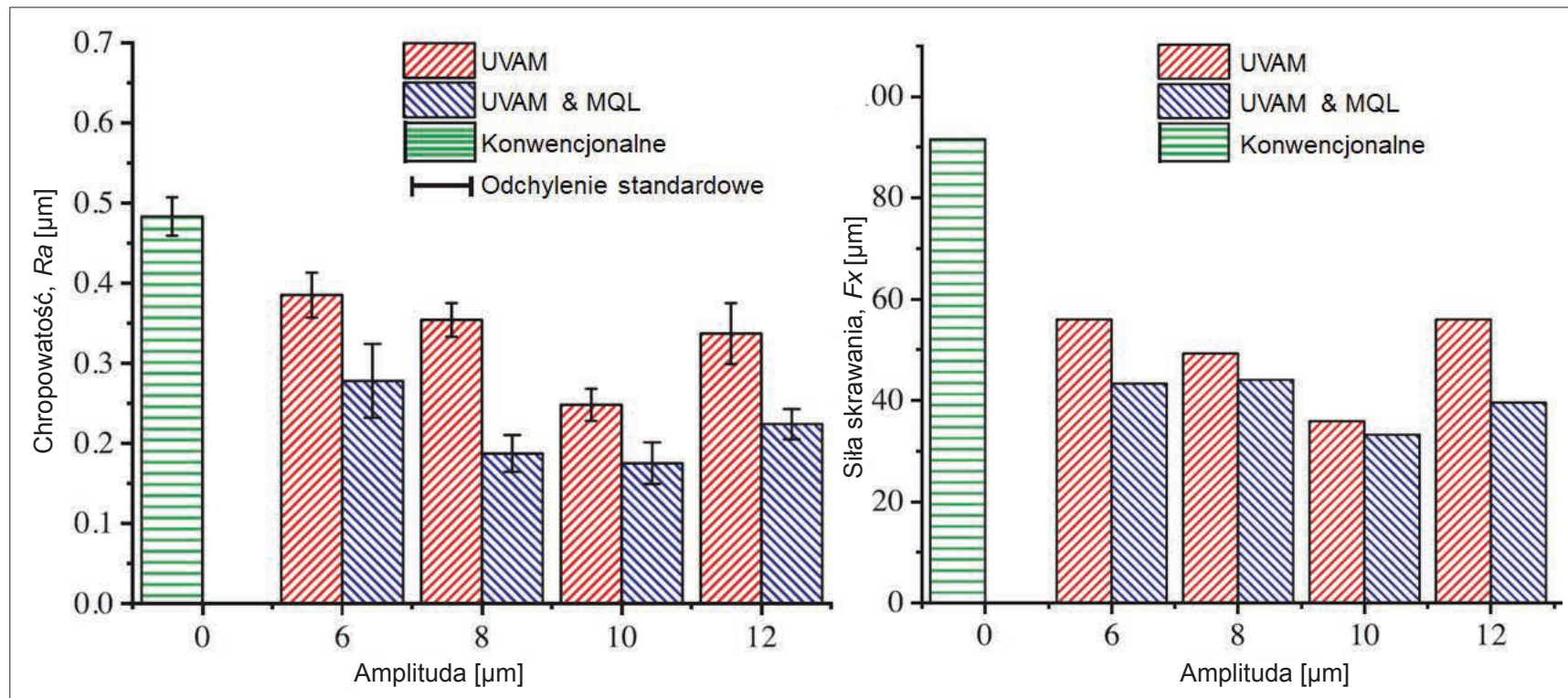

Fig. 7. Effect of vibration amplitudes on average cutting force and surface roughness under different methods of machining TC4 [16] Rys. 7. Wpływ amplitudy drgań na średnią siłę skrawania i chropowatość powierzchni przy różnych metodach obróbki TC4 [16] 
obrobionej powierzchni oraz $\mathrm{w}$ pewnym stopniu zredukować zużycie narzędzia - rys. 6 [15].

Ta sama metodyka została zastosowana do frezowania stopu TC4 [16]. Również tu chropowatość powierzchni uzyskana dzięki UVAM\&MQL w porównaniu z uzyskaną konwencjonalnie i w UVAM była niższa odpowiednio o około $30 \div 50 \%$ i $20 \div 30 \%$ (rys. 5). Co ciekawe, przerywany kontakt narzędzia z obrabianym przedmiotem może zapewnić dostęp do strefy między nimi bardzo drobnym kroplom i sprężonemu powietrzu o niskiej temperaturze pod wysokim ciśnieniem. Siłę skrawania można znacznie zmniejszyć zarówno dzięki UVAM, jak i UVAM\&MQL - rys. 7.

\section{Połączenie wspomagania drganiami ultradźwiękowymi z chłodzeniem wysokociśnieniowym}

Chłodzenie pod wysokim ciśnieniem (HPC) jest szeroko i z dobrymi wynikami stosowane w ostatnich latach do obróbki stopów tytanu. Podobnie jak w przypadku MQL, drgania ultradźwiękowe umożliwiają pełny dostęp strumienia pod wysokim ciśnieniem do krawędzi skrawającej narzędzia. Trwałość ostrza podczas toczenia Ti6Al4V została znacznie wydłużona przez HPC w porównaniu z chłodzeniem zalewowym [17]. Efekt ten jest tym silniejszy, im wyższe jest ciśnienie chłodziwa (rys. 8).

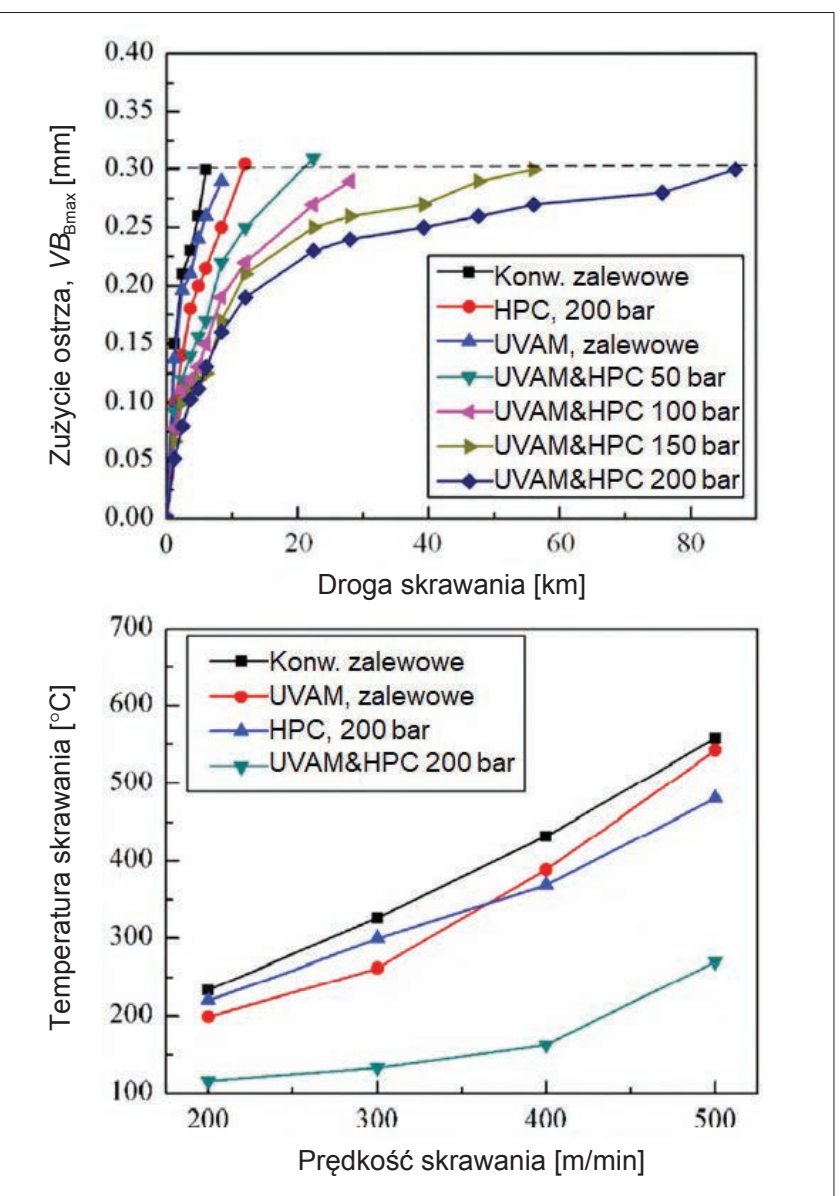

Fig. 8. Flank wear and cutting temperature under conventional cooling (CC), UVAM and UVAM\&HPC in turning of Ti6Al4V [17]

Rys. 8. Zużycie powierzchni przyłożenia i temperatura w strefie skrawania w warunkach chłodzenia konwencjonalnego (CC), obróbki UVAM i UVAM\&HPC przy toczeniu Ti6AI4V [17]
Kombinacja UVAM i HPC (UVAM\&HPC) może zmniejszyć siłę główną i siłę posuwową o $15 \div 45 \%$, przy prędkości skrawania $200 \div 400 \mathrm{~m} / \mathrm{min}$. Temperatura w strefie skrawania również ulega znacznemu obniżeniu (rys. 8).

\section{Wiercenie wspomagane drganiami o niskiej częstotliwości}

Ciągłe tworzenie się poskręcanych wiórów przy dużym obciążeniu termicznym jest krytycznym wyzwaniem podczas konwencjonalnego wiercenia stopu tytanu Ti6Al4V. Dodatkowo niepożądane efekty uboczne będą miały wpływ na jakość wierconego otworu, jak również na wydajność obróbki, co w przemyśle lotniczym jest niedopuszczalne.

Zbadano wpływ drgań o niskiej częstotliwości $(\sim 100 \mathrm{~Hz})$ wspomagających wiercenie (LF-VAD) na morfologię wiórów, mikrostrukturę warstwy wierzchniej i stan naprężeń szczątkowych [18]. Metoda wykazała znaczne obniżenie temperatury procesu skrawania dzięki przejściu ze skrawania ciągłego na przerywane (rys. 9). LF-VAD poprawiło naprężenia szczątkowe do wartości ściskających, co ma znaczący wpływ na trwałość zmęczeniową części. Powstały mechanizm odprowadzania wiórów zwiększył błąd wielkości wierconego otworu, osiągając IT9 na standardowych stopniach tolerancji w połączeniu z ponad $50 \%$ redukcją chropowatości powierzchni otworu.
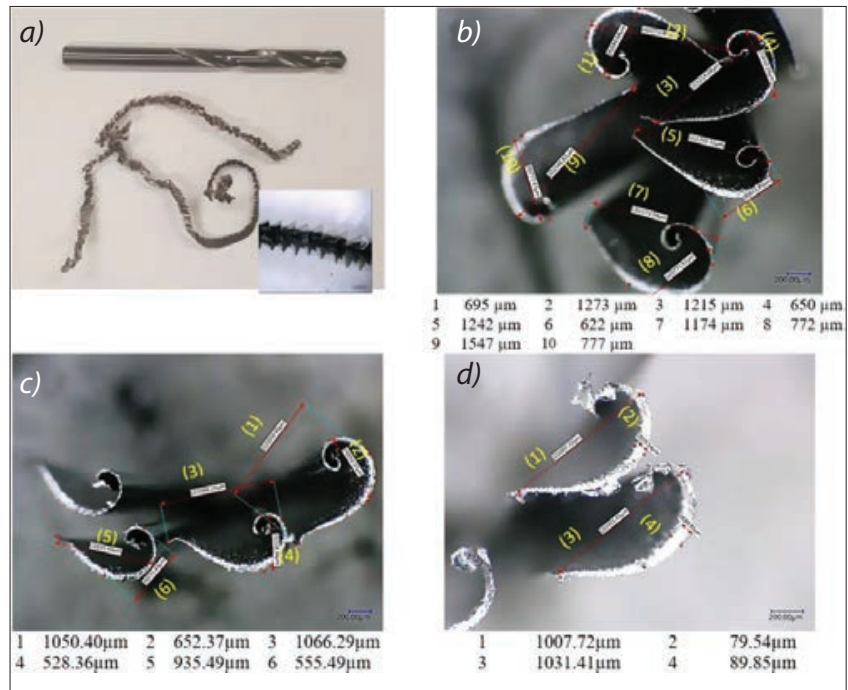

Fig. 9. Effect of the LF-VAD amplitude (Am) on the Ti6Al4V chip morphology: a) conventional drilling, b) $A m=0.07 \mathrm{~mm}, c) A m=0.1 \mathrm{~mm}$, d) $\mathrm{Am}=0.16 \mathrm{~mm}$ [18]

Rys. 9. Wpływ amplitudy LF-VAD (Am) na morfologię wiórów Ti6Al4V: a) wiercenie konwencjonalne, b) $A m=0,07 \mathrm{~mm}, c) A m=0,1 \mathrm{~mm}$, d) $\mathrm{Am}=0,16 \mathrm{~mm}[18]$

Pęknięcia cykliczne, w których wzdłuż pasma ścinania zlokalizowane są duże pęknięcia i mikropęknięcia, są dominującym mechanizmem powstawania wiórów zębatych przy wierceniu Ti6Al4V z LF-VAD. Tworzenie się tych pęknięć wykazało znacząca zależność od amplitudy drgań [19]. Wyniki świadczyły o zmniejszeniu współczynnika grubości wióra oraz wzroście stopnia segmentacji przy zwiększaniu amplitudy drgań rys. 10 . 


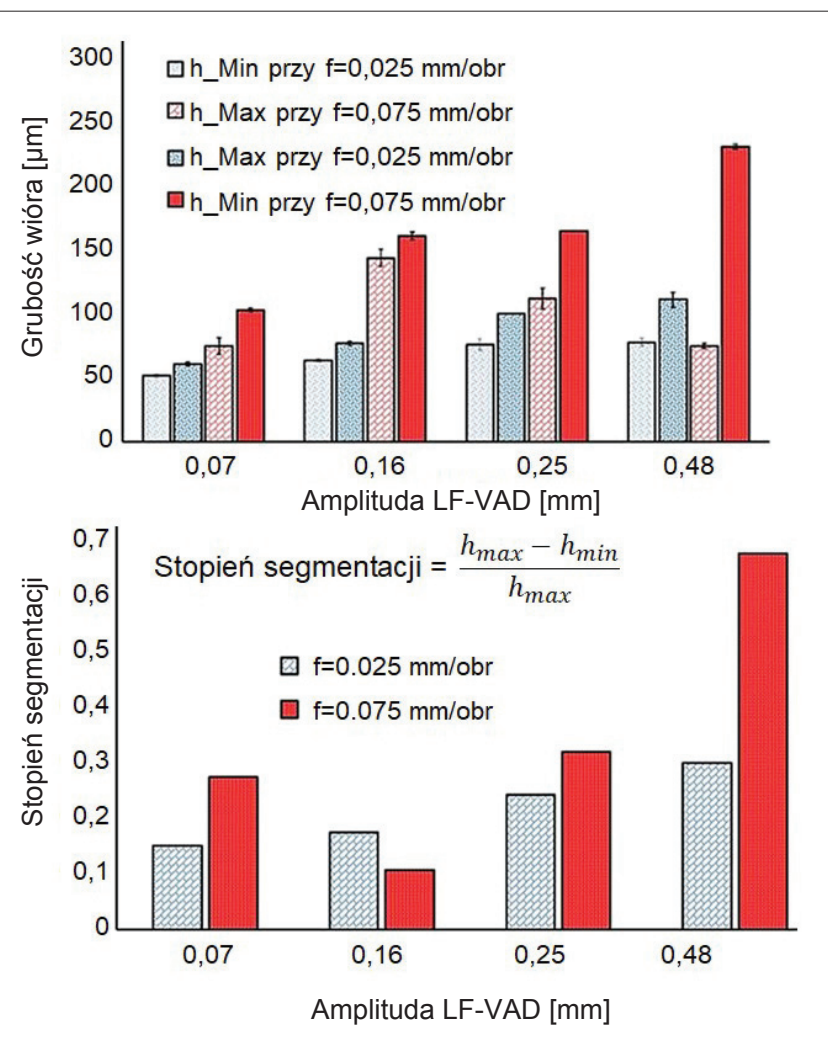

Fig. 10. Geometric characterization for LF-VAD chips cross section for $h_{\text {max }} h_{\min }$ and segmentation degree [19]

Rys. 10. Charakterystyka geometryczna dla przekroju poprzecznego wiórów przy LF-VAD dla $h_{\max } h_{\min }$ oraz stopień segmentacji [19]

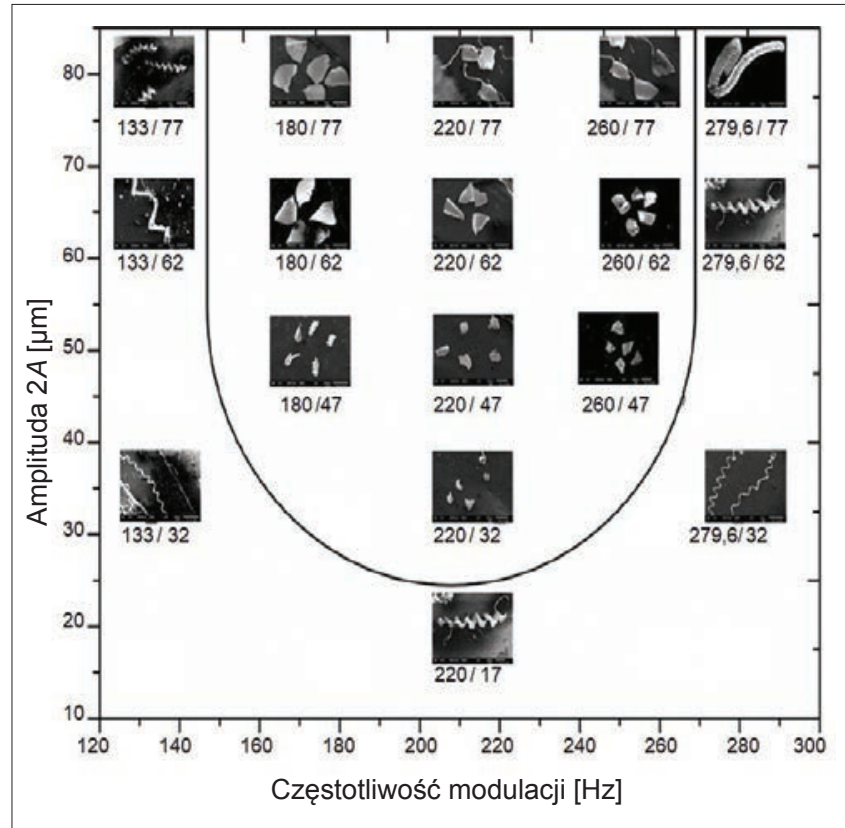

Fig. 11. Frequency-amplitude graph showing short chips generation region during LF-VAD of Ti6AI4V [20]

Rys. 11. Wykres częstotliwość-amplituda pokazujący region generacji krótkich wiórów podczas LF-VAD stopu Ti6Al4V [20]

Podczas wiercenia wspomaganego drganiami o niskiej częstotliwości Ti6Al4V krótkie wióry powstają tylko w określonych zakresach amplitud i częstotliwości w postaci charakterystycznej krzywej $U$. Może ona służyć jako gotowy przewodnik do wyboru odpowiednich warunków modulacji dla przerwanej generacji wiórów - rys. 11 [20].
Zastosowanie lekkich materiałów, takich jak stosy CFRP/Ti6Al4V, w przemyśle lotniczym służy poprawie właściwości fizycznych i mechanicznych wyrobów. Jednakże proces wiercenia heterogenicznych struktur wiąże się zazwyczaj z niedopuszczalnym rozwarstwieniem CFRP, niedokładnością otworu oraz dużym zużyciem narzędzia. Trudności w obróbce wynikają z dużego obciążenia termicznego i słabego odprowadzania wiórów.

Wiercenie wspomagane drganiami o niskiej częstotliwości (LF-VAD) wykazuje duży potencjał w pokonaniu tych wyzwań. $\mathrm{W}$ porównaniu $\mathrm{z}$ wierceniem konwencjonalnym (CD) LF-VAD (2,5 cyklu/obr)

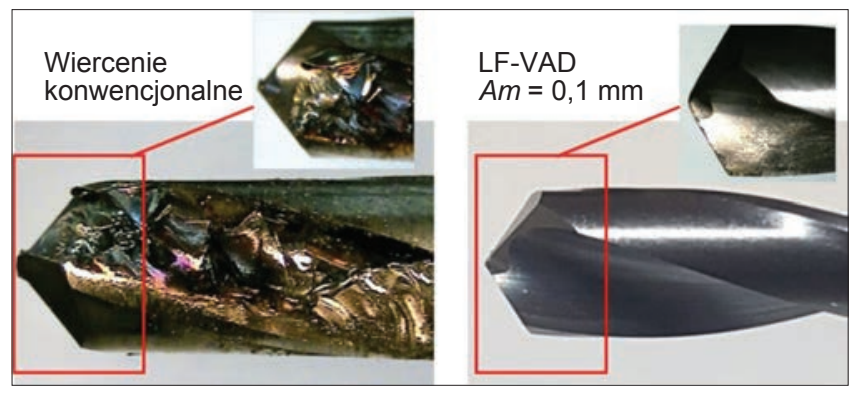

Fig. 12. The effect of cutting technique on cutting tool during CFRP/ /Ti6Al4V stack material [21]

Rys. 12. Wpływ techniki skrawania na narzędzie skrawające podczas obróbki stosu CFRP/Ti6AI4V [21]
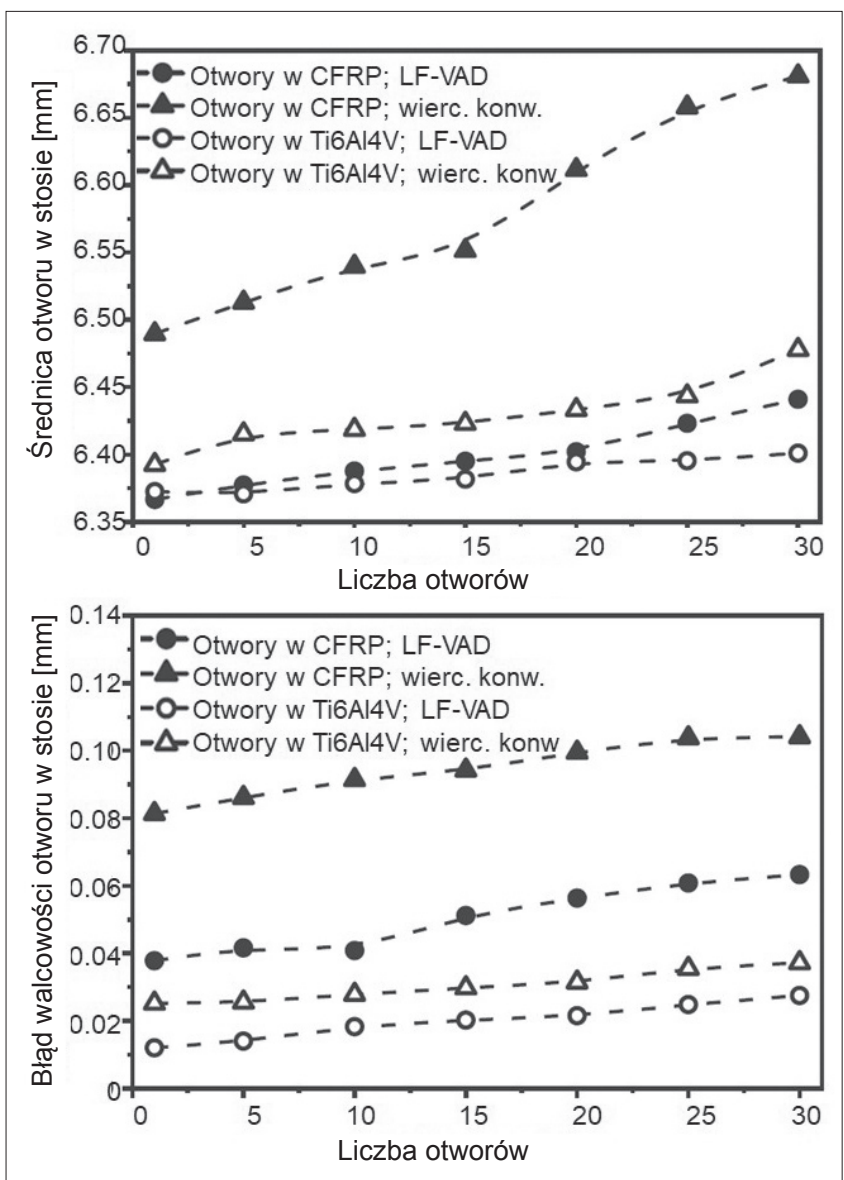

Fig. 13. Comparison of hole diameters and cylindricity errors of cut CFRP/Ti6Al4V stacks between the LF-VAD and CD processes in terms of the number of holes [22]

Rys. 13. Porównanie średnic otworów i błędów walcowości stosów CFRP/Ti6Al4V obrabianych procesami LF-VAD i CD w funkcji liczby otworów [22] 


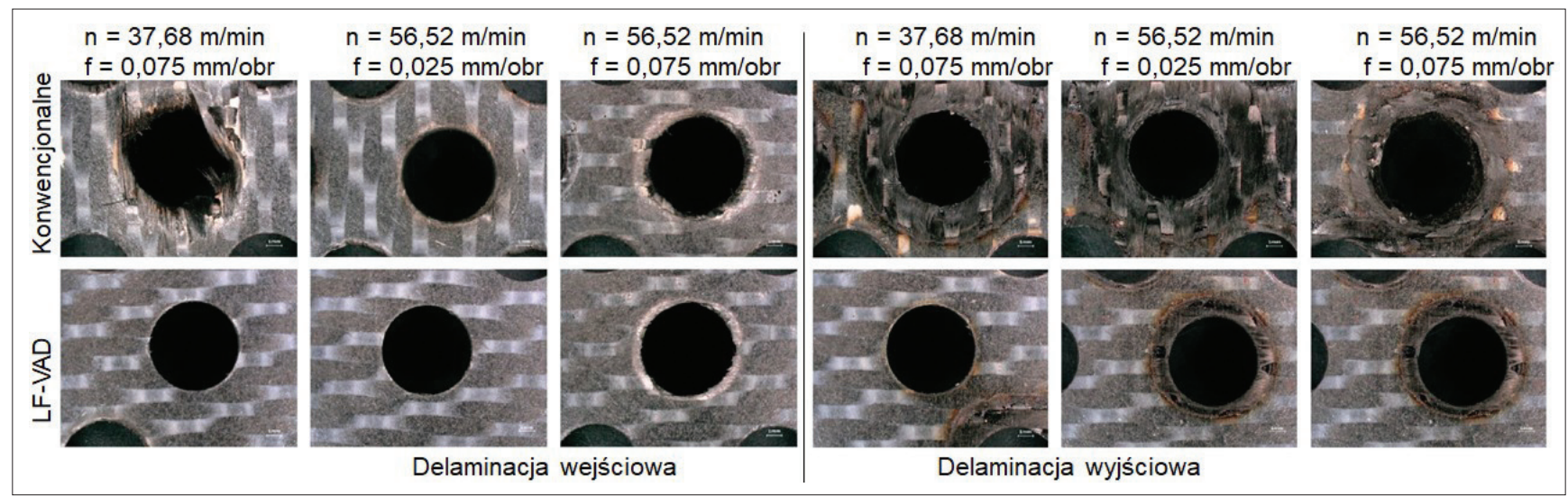

Fig. 14. The effect of machining technique on entry and exit delamination at the end of machining with each machining parameter [23] Rys. 14. Wpływ techniki obróbki na delaminację wejściową i wyjściową na koniec obróbki ze wszystkimi parametrami [23]

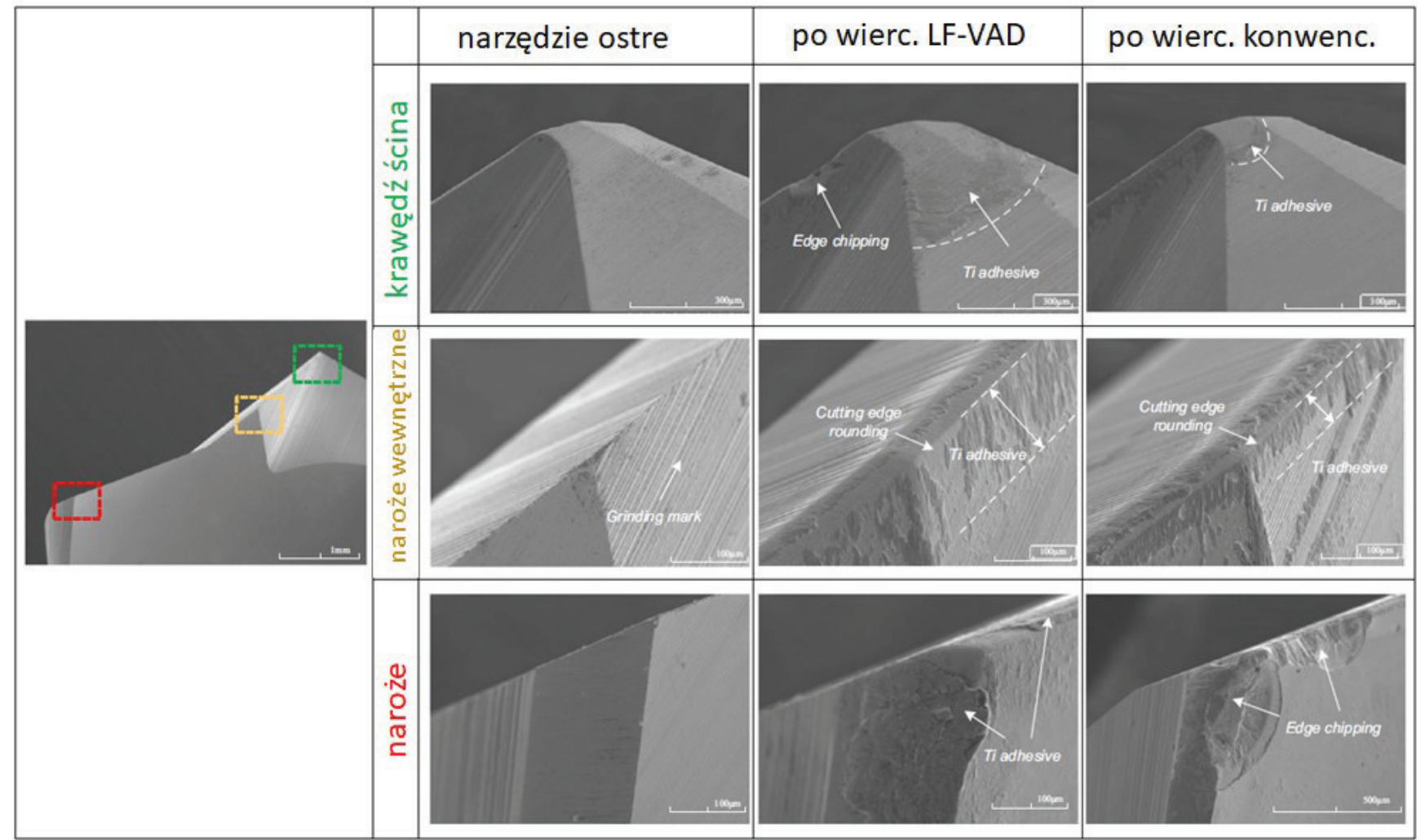

Fig. 15. Comparisons of tool wear patterns for the drills used in CFRP/Ti stack drilling [24] Rys. 15. Porównanie zużycia wierteł stosowanych do wiercenia stosu CFRP/Ti [24]

powoduje dynamiczną zmianę grubości nieobrobionych wiórów, co poprawia ich odprowadzanie (rys. 12 [21]); zmniejsza obciążenie cieplne obróbki i zużycie powierzchni przyłożenia; zwiększa dokładność geometryczną (rys. 13 [22]) oraz zmniejsza rozwarstwienie na wejściu i wyjściu dla wszystkich badanych parametrów obróbki (rys. 14 [23]).

Oprócz omówionych pozytywnych skutków zastosowania LF-VAD ciekawy efekt zaobserwowano dla stosów CFRP/Ti, gdzie płyta CFRP i płyta Ti były poddawane procesom LF-VAD i CD. Ze względu na zmianę kąta wypadkowej prędkości skrawania i grubości warstwy skrawanej, LF-VAD powoduje wydłużenie czasu kontaktu narzędzia z przedmiotem obrabianym na powierzchni natarcia i powierzchni przyłożenia, co bezpośrednio prowadzi do bardziej równomiernego zużycia narzędzia i efektu samoostrzenia krawędzi skrawającej. Wiertło stosowane w LF-VAD ma mniejszą całkowitą objętość zużycia, bardziej równomierny jest rozkład zużycia, większy kąt natarcia, większy kąt przyłożenia, mniejszy kąt ostrza i mniejszy promień krawędzi. W szczególności: im mniejszy promień obrotu, tym silniejszy efekt samoostrzenia - rys. 15 [24].

\section{Wnioski}

Oprócz znanych zalet ultradźwiękowej obróbki wspomaganej wibracjami (UVAM), połączenie UVAM ze smarowaniem minimalnym (UVAM\&MQL) zwiększyło jej skuteczność w redukcji chropowatości powierzchni, temperatury i sił skrawania oraz umożliwiło uniknięcie tworzenia się niebezpiecznej dla zdrowia operatora mgły olejowej. Dodanie wibracji do chłodzenia wysokociśnieniowego, tak jak w przypadku 
UVAM\&MQL, ułatwiło dostęp chłodziwa do krawędzi skrawającej, co jeszcze bardziej poprawiło efektywność obróbki stopów lotniczych. Zastosowanie drgań o niskiej częstotliwości do wiercenia superstopów znacznie poprawia łamanie i ewakuację wiórów, a w przypadku stosów poprawia jakość wykonywanych otworów, zmniejsza delaminację i zwiększa trwałość ostrza.

Pomimo znacznych, opisanych tu osiągnięć we wspomaganiu drganiami obróbki materiałów lotniczych, techniki te nie sa łatwe do zastosowania i w każdym przypadku należy przeprowadzić odpowiednie próby $\mathrm{w}$ celu sprawdzenia możliwości ich wykorzystania, a następnie optymalizacji parametrów drgań. Można się jednak spodziewać szybkiego rozwoju tych technik, relacjonowanego niemal na bieżąco w literaturze naukowej.

Pełną, angielska wersję artykułu można znaleźć: Jemielniak K. "Review of new developments in machining of aerospace materials". Journal of Machine Engineering. 21, 1 (2021): 22-55, doi. org/10.36897/jme/132905.

\section{LITERATURA}

[1] Jemielniak K. "New developments in cooling techniques for machining superalloys" [„Nowe osiągnięcia w technikach chłodzenia przy obróbce superstopów"]. Mechanik. 7 (2021) 6-16, https://doi.org/10.17814/mechanik.2021.7.9.

[2] Chen W., Huo D., Shi Y., Hale J.M. "State-of-the-art review on vibration-assisted milling: principle, system design, and application". Int J Adv Manuf Technol. 97 (2018): 2033-2049, https://doi.org/10.1007/s00170-018-2073-z.

[3] Zheng L., Chen W., Huo D. "Review of vibration devices for vibration-assisted machining". Int J Adv Manuf Technol. 108 (2020): 1631-1651, https://doi.org/10.1007/ s00170-020-05483-8.

[4] Rinck P.M., Gueray A., Kleinwort R., Zaeh M.F. “Experimental investigations on longitudinal-torsional vibration-assisted milling of Ti-6Al-4V". Int J Adv Manuf Technol. 108 (2020): 3607-3618, https://doi.org/10.1007/s00170020-05392-w.

[5] Liu Q., Xu J., Yu H. "Experimental study of tool wear and its effects on cutting process of ultrasonic-assisted milling of Ti6Al4V". Int J Adv Manuf Technol. 108 (2020): 2917-2928, https://doi.org/10.1007/s00170-020-05593-3.

[6] Zhu L., Ni C., Yang Z., Liu C. "Investigations of microtextured surface generation mechanism and tribological properties in ultrasonic vibration-assisted milling of Ti-6Al-4V". Precision Engineering. 57 (2019): 229-243, https:// doi.org/10.1016/j.precisioneng.2019.04.010.

[7] Gao J., Jin X. "Effects of Ultrasonic Vibration Assistance on Chip Formation Mechanism in Cutting of Ti-6Al-4V". J. Manuf. Sci. Eng. 141/12 (2019): 121007, https://doi. org/10.1115/1.4045129.

[8] Bai W., Bisht A., Roy A., Suwas S., Sun R., Silberschmidt V.V. "Improvements of machinability of aerospace-grade Inconel alloys with ultrasonically assisted hybrid machining". Int J Adv Manuf Technol. 101 (2019): 1143-1156, https:// doi.org/10.1007/s00170-018-3012-8.

[9] Liu Y., Liu Z., Wang X., Huang T. "Experimental study on tool wear in ultrasonic vibration-assisted milling of $\mathrm{C} / \mathrm{SiC}$ composites". Int J Adv Manuf Technol. 107 (2020): 425436, https://doi.org/10.1007/s00170-020-05060-z.

[10] Kim J., Bai W., Roy A., Jones L.C.R., Ayvar-Soberanis S., Silberschmidt V.V. "Hybrid machining of metal-matrix composite". Procedia CIRP. 82 (2019): 184-189, https://doi. org/10.1016/j.procir.2019.04.162.
[11] Niu Q., Jing L., Wang C., Li S., Qiu X., Li C., Xiang D. “Study on effect of vibration amplitude on cutting performance of $\mathrm{SiCp} / \mathrm{Al}$ composites during ultrasonic vibration-assisted milling". Int J Adv Manuf Technol. 106 (2020): 2219-2225, https://doi.org/10.1007/s00170-019-04796-7.

[12] Hussein R., Sadek A., Elbestawi M.A., Attia M.H. "Elimination of delamination and burr formation using high-frequency vibration-assisted drilling of hybrid CFRP/ /Ti6Al4V stacked material". Int J Adv Manuf Technol. 105 (2019): 859-873, https://doi.org/10.1007/s00170019-04248-2.

[13] Wei L., Wang D. "Comparative study on drilling effect between conventional drilling and ultrasonic-assisted drilling of Ti-6Al-4V/Al2024-T351 laminated material". Int J Adv Manuf Technol. 103 (2019): 141-152, https://doi. org/10.1007/s00170-019-03507-6.

[14] Yan L., Zhang Q., Yu J. "Effects of continuous minimum quantity lubrication with ultrasonic vibration in turning of titanium alloy". Int J Adv Manuf Technol. 98 (2018): 827-837, https://doi.org/10.1007/s00170-018-2323-0.

[15] Ni C., Zhu L., Yang Z. "Comparative investigation of tool wear mechanism and corresponding machined surface characterization in feed-direction ultrasonic vibration assisted milling of Ti-6Al-4V from dynamic view". Wear. 436-437 (2019): 203006, https://doi.org/10.1016/ j.wear.2019.203006.

[16] Ni C., Zhu L. "Investigation on machining characteristics of TC4 alloy by simultaneous application of ultrasonic vibration assisted milling (UVAM) and economical-environmental MQL technology". Journal of Materials Processing Tech. 278 (2020): 116518, https://doi.org/10.1016/ j.jmatprotec.2019.116518.

[17] Lu Z., Zhang D., Zhang X., Peng Z. "Effects of high-pressure coolant on cutting performance of high-speed ultrasonic vibration cutting titanium alloy". Journal of Materials Processing Tech. 279 (2020): 116584, https://doi.org/10.1016/j.jmatprotec.2019.116584.

[18] Hussein R., Sadek A., Elbestawi M.A., Attia M.H. "Surface and microstructure characterization of low-frequency vibration-assisted drilling of Ti6Al4V". Int J Adv Manuf Technol. 103 (2019): 1443-1457, https://doi.org/10.1007/ s00170-019-03608-2.

[19] Hussein R., Sadek A., Elbestawi M.A., Attia M.H. "Effect of process parameters on chip formation during vibration-assisted drilling of Ti6Al4V". Int J Adv Manuf Technol. 106 (2020): 1105-1119, https://doi.org/10.1007/s00170019-04627-9.

[20] Singh M., Dhiman S., Singh H., Berndt C.C. "Optimization of modulation-assisted drilling of Ti-6Al-4V aerospace alloy via response surface method". Materials and Manufacturing Processes. 35/12 (2020): 1313-1329, https://doi.org /10.1080/10426914.2020.1772487.

[21] Hussein R., Sadek A., Elbestawi M.A., Attia M.H. "Low-frequency vibration-assisted drilling of hybrid CFRP/ Ti6Al4V stacked material". Int J Adv Manuf Technol. 98 (2018): 2801-2817, https://doi.org/10.1007/s00170018-2410-2.

[22] Xu J., Li C., Chen M., Ren F. “A comparison between vibration assisted and conventional drilling of CFRP/Ti6Al4V stacks". Materials and Manufacturing Processes. 34/10 (2019): 1182-1193, https://doi.org/10.1080/10426914. 2019.1615085.

[23] Hussein R., Sadek A., Elbestawi M.A., Attia M.H. "An investigation into tool wear and hole quality during low-frequency vibration-assisted drilling of CFRP/Ti6Al4V stack". J. Manuf. Mater. Process. 3 (2019): 63, https://doi. org/10.3390/jmmp3030063.

[24] Yang H., Chen Y., Xu J., Ladonne M., Lonfier J., Fu Y. “Tool wear mechanism in low-frequency vibration-assisted drilling of CFRP/Ti stacks and its individual layer". Int J Adv Manuf Technol. 104 (2019): 2539-2551, https://doi. org/10.1007/s00170-019-03910-z. 